\title{
Morphophysiological quality of yerba mate plantlets produced by mini-cuttings
}

\section{Qualidade morfofisiológica de mudas de erva-mate produzidas por miniestaquia}

\author{
Nathalia Pimentel ${ }^{1}$; Kelen Haygert Lencina ${ }^{2}$; Marina Favarin Pedroso ${ }^{3}$; \\ Tamires Manfio Somavilla ${ }^{4}$; Dilson Antônio Bisognin ${ }^{5 *}$
}

\begin{abstract}
The objective of this study was to evaluate the morphophysiological quality of yerba mate plantlets (Ilex paraguariensis A. St.-Hil.) produced by mini-cutting at four different times of year and cultivated in different containers. For the rooting of mini-cuttings, shoots of four yerba mate clones were collected four times during the year (April, July and October 2014 and January, 2015), cut into single-budded mini-cuttings and planted in equal proportions of pine bark-based commercial substrate, vermiculite and coarse sand. After 60 days of cultivation in a wet chamber, the rooted mini-cuttings were transferred to different containers: a $100 \mathrm{~cm}^{3}$ rigid polyethylene tube container and 500,1500 and $3000 \mathrm{~cm}^{3}$ polyethylene bags containing pine bark-based commercial substrate and underground soil $(2: 1 \mathrm{v} / \mathrm{v})$. A completely randomized design was used in a $4 \times 4$ factorial scheme, with five replications ranging from 5 to 20 mini-cuttings per experimental unit. The plantlets were evaluated for survival percentage, shoot height, stem diameter, shoot height/stem diameter ratio and number of leaves at 30,60,90 and 120 days of cultivation. At 120 days of cultivation, 10 plantlets from each treatment were randomly picked to evaluate shoot and root dry mass, Dickson quality index, shoot height, surface area, total volume and number of root tips. The best combinations of shoot height, length, surface area, total volume and number of root tips and Dickson quality index were found in plantlets produced in July, 2014, followed by plantlets produced in October,2014 and January, 2015. The polyethylene bags allowed the production of yerba mate plantlets with satisfactory quality of shoot and roots, regardless of the volume. Yerba mate plantlets can be produced by mini-cutting from July to January in polyethylene bags.

Key words: Ilex paraguariensis. Plantlet production. Polyethylene bags. Season of the year. Tube containers.
\end{abstract}

\section{Resumo}

O objetivo deste estudo foi avaliar a qualidade morfofisiológica de mudas de erva-mate (Ilex paraguariensis A. St.-Hil.) produzidas por miniestaquia em quatro épocas do ano e cultivadas em diferentes recipientes. Para o enraizamento das miniestacas, brotações de quatro clones de erva-mate foram coletadas em quatro épocas do ano (Abril, Julho e Outubro de 2014 e Janeiro de 2015), seccionadas em miniestacas de gema única e cultivadas em iguais proporções de substrato comercial à base de casca

\footnotetext{
1 Enga Florestal, M.e, Discente do Curso de Doutorado, Programa de Pós-Graduação em Engenharia Florestal, Universidade Federal de Santa Maria, UFSM, Santa Maria, RS, Brasil. E-mail: nathaliapimentel@outlook.com

2 Eng ${ }^{\mathrm{a}}$ Florestal, Dr ${ }^{\mathrm{a}}$ em Engenharia Florestal, UFSM, Santa Maria, RS, Brasil. E-mail: khaygert@gmail.com

3 Discente, Curso de Graduação em Engenharia Florestal, UFSM, Santa Maria, RS, Brasil. E-mail: marinafengflorestal@gmail.com

4 Enga Florestal, Discente do Curso de Mestrado, Programa de Pós-Graduação em Engenharia Florestal, UFSM, Santa Maria, RS, Brasil. E-mail: tamiresengenheiraflorestal@gmail.com

5 Eng ${ }^{\circ}$ Agr ${ }^{\circ}$, Prof. PhD, Departamento de Fitotecnia, UFSM, Santa Maria, RS, Brasil. E-mail: dbisognin@gmail.com

* Author for correspondence.
} 
de pinus, vermiculita média e areia de granulometria grossa. Após 60 dias de cultivo em câmara úmida, as miniestacas enraizadas foram transferidas para diferentes recipientes: tubete de polietileno rígido de $100 \mathrm{~cm}^{3}$ e sacos de polietileno de 500,1500 e $3000 \mathrm{~cm}^{3}$, contendo substrato comercial à base de casca de pinus e terra de subsolo $(2: 1 \mathrm{v} / \mathrm{v})$. Foi utilizado um delineamento inteiramente casualizado em esquema fatorial 4 x 4, com cinco repetições variando de 5 a 20 miniestacas por unidade experimental. Aos 30, 60, 90 e 120 dias de cultivo, as mudas de erva-mate foram avaliadas quanto a porcentagem de sobrevivência, altura da parte aérea, diâmetro de colo, relação entre a altura da parte aérea e diâmetro de colo e número de folhas. Somente aos 120 dias de cultivo, 10 mudas de cada tratamento foram tomadas ao acaso para a avaliação da relação massa seca da parte aérea e das raízes, índice de qualidade de Dickson, comprimento total, área superficial, volume total e número de extremidades das raízes. Miniestacas de erva-mate coletadas em julho de 2014 resultaram em mudas com maior altura da parte aérea, comprimento, área superficial, volume total e número de extremidades das raízes e índice de qualidade de Dickson, seguidas daquelas coletadas em outubro de 2014 e janeiro de 2015. Os sacos de polietileno, independentemente do volume, permitiram a produção de mudas de erva-mate com qualidade satisfatória tanto da parte aérea quanto do sistema radicial. Mudas de erva-mate de alta qualidade morfofisiológica podem ser produzidas por miniestaquia durante os meses de julho a janeiro e cultivadas em sacos de polietileno.

Palavras-chave: Épocas do ano. Ilex paraguariensis. Produção de mudas. Sacos de polietileno. Tubetes.

\section{Introduction}

Yerba mate (Ilex paraguariensis A. St.-Hil.) is a native tree species of subtropical regions of South America (GNOATTO et al., 2007) and plays an important socioeconomic role in Brazil, especially in several municipalities in the southern region of the country (CARVALHO, 2003). In the beginning of the 19th century, yerba mate became the second most exported product in Brazil (WENDLING et al., 2007). However, its average national productivity decreased from 17.3 tons per hectare in 1990 to 6.7 tons per hectare in 2012 (IBGE, 2012), indicating that yerba mate foliar mass production in Brazil is in decline. It is believed that the cause of this reduction is largely due to the use of low-quality seedlings in yerba mate plantations, which mainly produce using seeds. Thus, in order to increase productivity, it is essential to establish techniques that provide the production of plantlets of yerba mate with high genetic and morphophysiological quality, that is, plants with high survival rate, satisfactory and balanced growth of the aerial part and the root system, both in the cultivation conditions in nurseries and after planting in the field, such as obtained with vegetative propagation.

Mini-cutting is a recent variation of the cutting technique (FERRIANI et al., 2010), which guarantees numerous advantages including crop uniformity, better adaptation of clones to local conditions and increased forest productivity (XAVIER; COMÉRIO, 1996). This is because vegetative propagation produces a plantlets that is genetically identical to the parent plant, which, when selected based on pre-defined criteria, provides important genetic gains for commercial plantations. In addition to the genetic characteristics of the propagated species, the specific management conditions of the plants in the nursery are factors that strongly influence the quality of the seedlings produced, and the practices used in each stage of production may vary according to the species and time of year (ALFENAS et al., 2009).

The time of the year may influence the growth and morphological quality of the seedlings since plant growth is divided into two main phases: a phase of intense growth, which occurs in the period between spring and summer, and a resting phase of shoot growth, which occurs between autumn and winter (STENZEL et al., 2005). Additionally, previous studies have found that lower temperatures during winter result in smaller increases in height and seedling diameter of Eucalyptus grandis W. Hill x E. urophylla S. T. Black (SOUZA et al., 2013).

In addition to the time of year, other factors influence the growth and development of the root 
and shoot, such as the type and size of container (DUMROESE et al., 2009). The type of container is of great importance for root system development in plantlets produced by vegetative propagation, since the adventitious roots formed in the mini-cuttings are more likely to develop root deformations as a result of more superficial initial growth and lack of definition of a pivoting root (HARTMANN; DALE, 1975). Furthermore, container dimensions determine the amount of required substrate, the space needed in the nursery, the labor and cost of transportation and the period necessary for acclimatization and arrival of the seedlings to the consumer. In this case, the study of the appropriate-sized container is relevant, since unnecessary volume results in increased costs of production, nursery maintenance, transportation and seedling distribution, which are among the most important factors that determine the cost of forest species seedling production (QUEIROZ; MELÉM JÚNIOR, 2001; LIMA et al., 2006; KOSTOPOULOU et al., 2011).

In order to cultivate forest species seedlings, the height of the container is generally more important than its diameter (GOMES et al., 1990). However, the diameter of the container was found to be more important in Pinus pinea (L.) seedlings, since depth had a smaller effect on seedling formation (DOMINGUEZ-LERENA et al., 2006). Thus, the ideal container dimensions vary according to the species and length of stay in the nursery (DUMROESE et al., 2009). For native forest species, several studies have sought to identify the ideal type and dimensions of containers for the production of seminal seedlings (SANTOS et al., 2000), such as Cabralea canjerana (Vell. Mart.) (GASPARIN et al., 2014), Jatropha curcas (L.) (AJALA et al., 2012), Cassia grandis (L.) (LEAL et al., 2015) and Anadenanthera macrocarpa (Benth. Brenan) (ALVES et al., 2012). However, no studies were found regarding containers for the production of plantlets of native forest species by vegetative propagation.

This study aimed to evaluate the morphological and physiological quality of yerba mate plantlets produced by mini-cutting in four season of the year and cultivated in containers of different types and sizes.

\section{Material and Methods}

The experiment was conducted from April 2014 to September 2015 in the greenhouse of the Center for Plant Improvement and Vegetative Propagation, Department of Plant Science at the Federal University of Santa Maria, Santa Maria, Rio Grande do Sul, Brazil.

The mini-clonal hedge was composed of ministumps of four clones of yerba mate (10SM07, 06SM17, 06SM15 and 06SM12) with an approximate age of three years, cultivated in a closed cultivation system with 10 x $10 \mathrm{~cm}$ spacing, with coarse sand as substrate and fertirrigation, adapted from Bandinelli et al. (2013). The nutrient solution was given to the mini-stumps twice a day for 15 minutes, which consisted of the following amounts of macronutrients and micronutrients ( $\mathrm{mg}$ $\mathrm{L}^{-1}$ ): $117.0 \mathrm{~N}$ in nitrate form; $15.75 \mathrm{~N}$ in ammonium form; 14.63 of $\mathrm{P} ; 131.62$ of $\mathrm{K}$; 84.0 of $\mathrm{Ca} ; 25.21$ of $\mathrm{Mg} ; 73.28$ of $\mathrm{S} ; 0.01$ of $\mathrm{B} ; 0.02$ of $\mathrm{Cu} ; 69.73$ of $\mathrm{Fe} ; 0.03$ of $\mathrm{Mn} ; 0.008$ of $\mathrm{Zn} ; 0.0016$ of Mo. The $\mathrm{pH}$ of the nutrient solution was maintained between 5.5 and 6.0 and electrical conductivity kept at $1.5 \mathrm{dS}$ $\mathrm{m}^{-1}$.

For rooting, sprouts were collected from the yerba mate mini-stumps maintained in a miniclonal hedge system in the four different season of the year (April, July and October 2014 and January, 2015) and sectioned into mini-cuttings with one bud of approximately $2.0 \mathrm{~cm}$ in length with one leaf reduced to $50 \%$ of its original area, as defined in preliminary tests. Then, the mini-cuttings were cultivated in polystyrene trays containing pine bark-based commercial substrate, vermiculite and coarse sand $(1: 1: 1 \mathrm{v} / \mathrm{v})$ and kept in a wet chamber with relative air humidity of approximately $85 \%$ provided by automated nebulization 8 times a day for 1 minute. 
After 60 days of cultivation in the wet chamber, optimum time for rooting of mini-cuttings of yerba mate (Figure 1A), the vegetative propagules rooted of the four clones were randomly distributed in different containers, being the genetic origin of these plantlets disregarded for the purpose to represent the genetic variability of this specie. The containers were filled with pine bark-based commercial substrate and subsoil $(2: 1 \mathrm{v} / \mathrm{v})$ without base fertilizer and had the following volumes and dimensions (height and width): $100 \mathrm{~cm}^{3}$ rigid polyethylene tube container $(14 \mathrm{x} 4 \mathrm{~cm}), 500 \mathrm{~cm}^{3}$ polyethylene bags $(10 \times 13 \mathrm{~cm}), 1500 \mathrm{~cm}^{3}$ polyethylene bags $(22 \mathrm{x}$ $15 \mathrm{~cm})$ and $3000 \mathrm{~cm}^{3}$ polyethylene bags $(25 \times 20$ $\mathrm{cm}$ ) (Figures 1B, 1C, 1D and 1E, respectively). The plantlets were arranged on benches and protected with $30 \%$ nylon shading (Figure 1F) throughout the experimental period. Irrigation was performed manually three times a week with a hand irrigator.

Figure 1. Mini-cuttings of yerba mate with one bud rooted in a wet chamber (A) and transferred to different containers: $100 \mathrm{~cm}^{3}$ rigid polyethylene tube container (B), $500 \mathrm{~cm}^{3}(1500 \mathrm{~cm})(\mathrm{C}), 1500 \mathrm{~cm}^{3}$ (D) and $3000 \mathrm{~cm}^{3}$ (E) polyethylene bags. The plantlets were arranged on protected benches with 30\% shading (F). After 120 days of cultivation, in each season of the year, 10 plantlets of each treatment were sectioned into the shoot and root system for morphophysiological analysis $(\mathrm{G}) . \mathrm{Bar}=1 \mathrm{~cm}$.
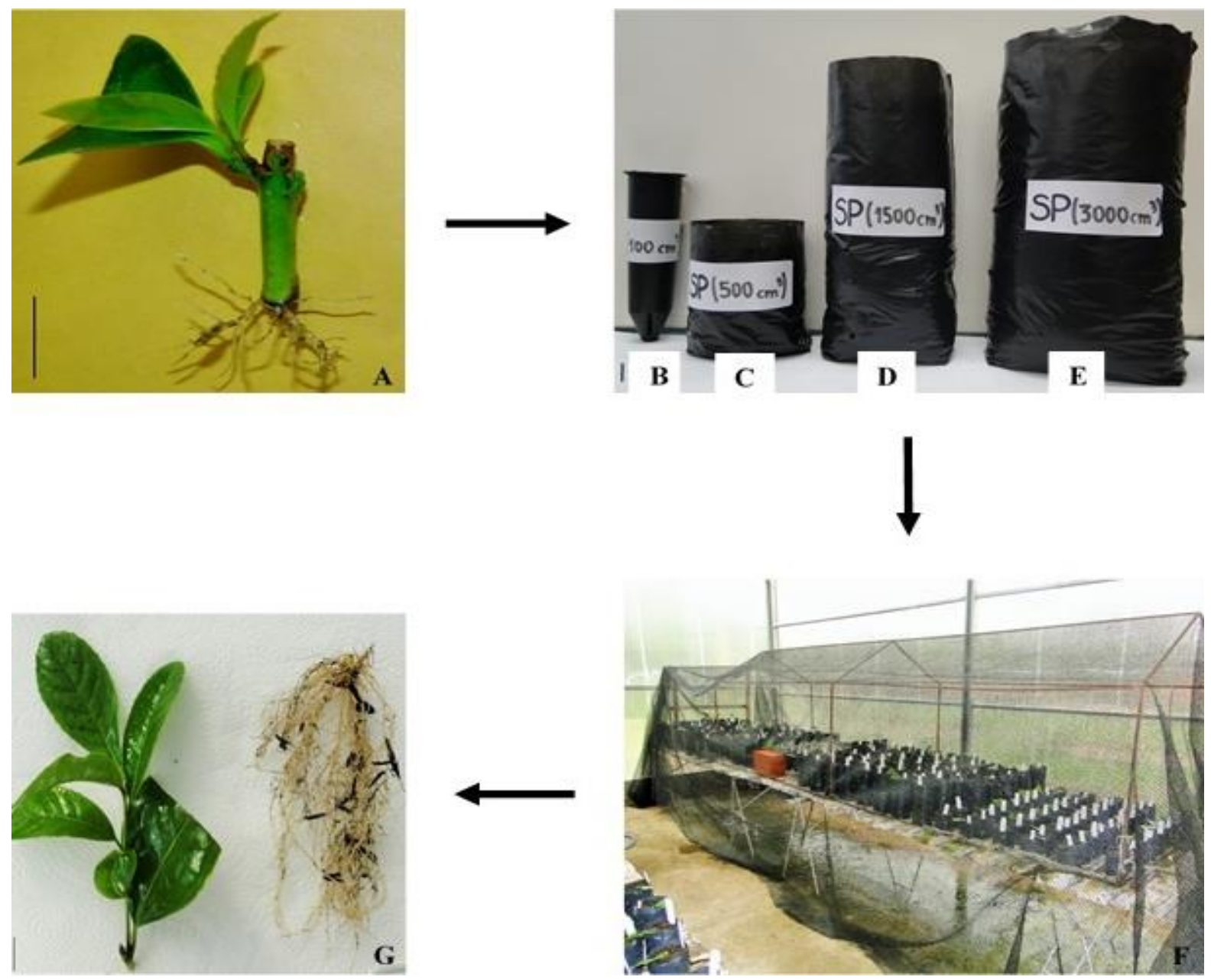
The yerba mate plantlets were evaluated at 30 , 60, 90 and 120 days of cultivation for survival percentage, number of leaves, shoot height $(\mathrm{cm})$, stem diameter $(\mathrm{mm})$ and the ratio between shoot height and stem diameter. Shoot height was measured from the substrate to the apex of the last formed leaf and stem diameter was measured at the substrate level with a digital caliper.

At 120 days of cultivation, in each season of the year, 10 plantlets by containers were randomly taken from each treatment to determine dry mass of the shoot and roots and analyze the root system. The plantlets were washed in tap water and sectioned at stem height and the shoot and root system (Figure $1 \mathrm{G})$ were placed separately in paper bags, which were kept in an oven at $105{ }^{\circ} \mathrm{C}$ until obtaining constant mass. Subsequently, the roots were scanned in an Epson 11000XL scanner and analyzed using WinRhizo Pro ${ }^{\circledR}$ software to determine the total length, surface area, total volume and number of root tips. Then, the relationship between shoot dry matter and root system dry matter (RSR) and Dickson quality index (DQI) was calculated according to the following equation: $\mathrm{DQI}=\mathrm{TDM} /(\mathrm{RHD}+\mathrm{RSR})$ (DICKSON et al., 1960), where TDM is the total dry mass and RHD is the ratio between shoot height and stem diameter.

During the experimental period, air temperature data (maximum and minimum) were obtained from the automatic meteorological station of the National Institute of Meteorology ( $8^{\circ} \mathrm{DISME} /$ INMET) about $100 \mathrm{~m}$ from the greenhouse and used to obtain the average air temperature, as recommended by FAO.

The experiment was a completely randomized $4 \times 4$ factorial design (seasons of the year $\mathrm{x}$ container types and volumes) with five replicates of 5 to 20 plantlets according to the number of rooted minicuttings at the time of the year. To meet normality, data percentage were transformed to arcsine $\sqrt{x / 100}$ and count and length to $\sqrt{x+0.5}$ and afterwards submitted to analysis of variance. The means of the treatments were compared by the Tukey test at the 5\% significance level.

\section{Results and Discussion}

The average air temperature was $18.5 ; 23.9$; $23.7 ; 21.9^{\circ} \mathrm{C}$ during the experimental period (from mini-cuttings collection in April, 2014; July, 2014; October, 2014 and January, 2015, respectively, until July, 2015).

There was no significant interaction between the season of the year and the containers tested in yerba mate plantlet production for survival percentage, number of leaves, shoot height, stem diameter and shoot height/stem diameter ratio. Likewise, there was no significant interaction between the season of the year and the containers for the dry mass relation between shoot and root, total length, surface area, total volume and number of root tips, as well as the quality index of Dickson plantlet at 120 days of cultivation.

The season showed a significant main effect for the survival percentage at 120 days, where the highest mean values were verified in the plantlets produced from mini-cuttings collected in July and October (91.0 and 90.0\%, respectively), without statistically differing from the plantlets produced in April (83.3\%). On the other hand, the lowest survival percentage was observed in the plantlets produced in January (76.0\%) (Figure 2A). Similar results were observed in seedlings of Jacaranda puberula Cham. produced in December, which presented a mean survival rate of $84.3 \%$ after 120 days of pricking out (ALMEIDA et al., 2005).

The season also affected the number of leaves and shoot height in all evaluations, with the best responses found in mini-cuttings collected in July (Figures 2B and 2C). It should be noted that minicuttings collected in July remained in the rooting stage for 60 days and only then were transferred to the different containers. Thus, this result may have occurred because the growth of these plantlets was evaluated between the months of October and January, which presented the higher average of air temperatures $\left(23.9^{\circ} \mathrm{C}\right)$ and consequently more intense vegetative growth (STENZEL et al., 2005). The results obtained in this study were similar to those reported by Luz et al. (2014), where the 
greatest growth of Melissa officinalis (L.) occurred at high temperatures. The authors concluded that the high temperatures increased the capacity to convert light into energy, thus increasing the photosynthetic efficiency and growth rate of plants (LUZ et al., 2014).

Figure 2. Survival percentage (A), number of leaves (B), shoot height (C) and stem diameter (D) of yerba mate plantlets produced by mini-cutting in four different seasons of the year, regardless of the genetic material, at 30, 60, 90 and 120 days of cultivation. Treatments followed by the same letter do not differ by the Tukey test at $5 \%$ error probability.

A

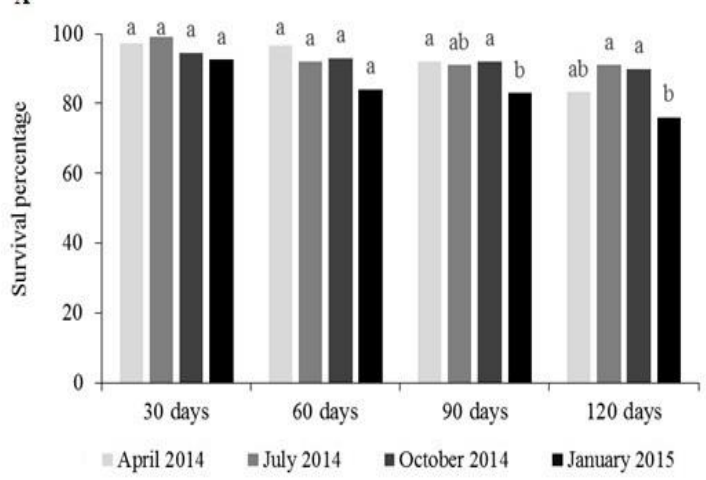

c

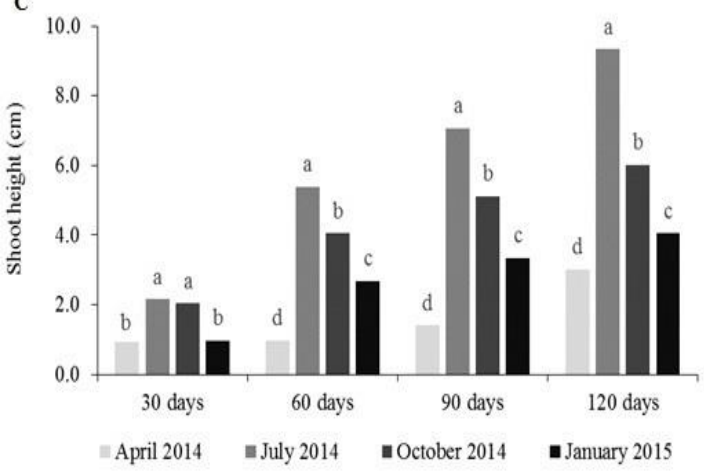

While collection in July favored the number of leaves and shoot height, collection in April resulted in plantlets with increased stem diameter (Figure 2D). As previously mentioned, these mini-cuttings were evaluated for growth only after the rooting period between the months of July and October, whichhave low average of air temperatures $\left(18.5^{\circ} \mathrm{C}\right)$ usually occurring during winter and spring seasons. During winter, the plant undergoes vegetative rest and accumulates carbohydrates (HAMMAN et al., 1996), which possibly resulted in increased stem diameter (Figure 2D) and, consequently, a lower shoot height/stem diameter ratio, since these variables are inversely proportional (CARNEIRO, 1995).
B

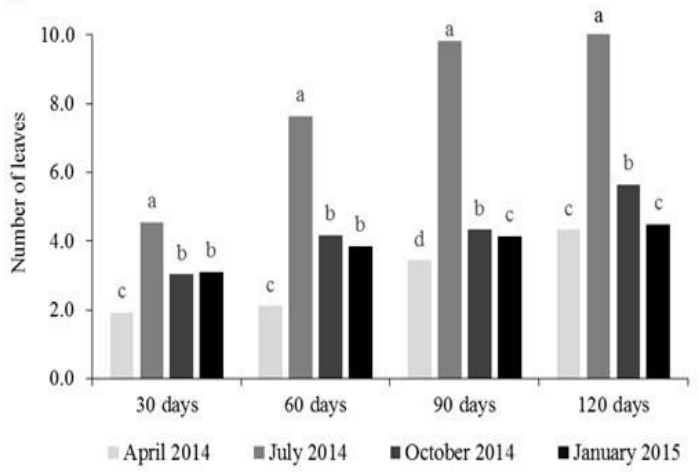

D

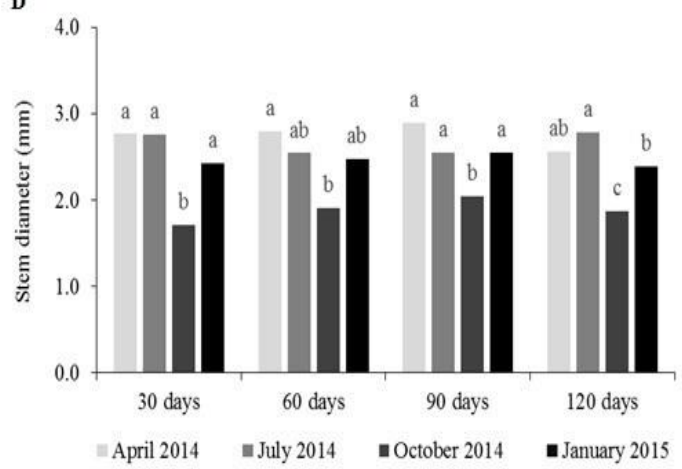

The relation between shoot and roots was influenced by the season, with the highest means found in yerba mate plantlets produced from minicuttings collected in April (5.8). However, despite being significantly higher than the other treatments, this value is above the ideal range (1.0 to 3.0 ) for the plantlets to perform satisfactorily in the field (WAKELEY, 1954; BARNETT, 1979). On the other hand, yerba mate plantlets produced from minicuttings collected in July, October and January, although statistically inferior, presented a mean shoot to roots relation within the ideal range (3.0, 2.1 and 2.4 respectively) (Figure 3A), which indicates that these plantlets have a balance between the shoot and root system and will more likely survive when planted in the field (CARNEIRO, 1995). 
Figure 3. The relationship between dry mass of the shoots and roots (A and B), total length (C and D), surface area ( $\mathrm{E}$ and $\mathrm{F}$ ), total volume $(\mathrm{G}$ and $\mathrm{H})$ and number of root tips (I and $\mathrm{J}$ ) of yerba mate plantlets produced by mini-cutting in four different times during the year (A, C, E, G and I) and in different containers (B, D, F, H and J), regardless of the genetic material, at 120 days of cultivation. $\mathrm{PB}=$ polyethylene bags and $\mathrm{PT}=$ polyethylene tube containers. Treatments followed by the same letter do not differ by the Tukey test at $5 \%$ error probability.

A
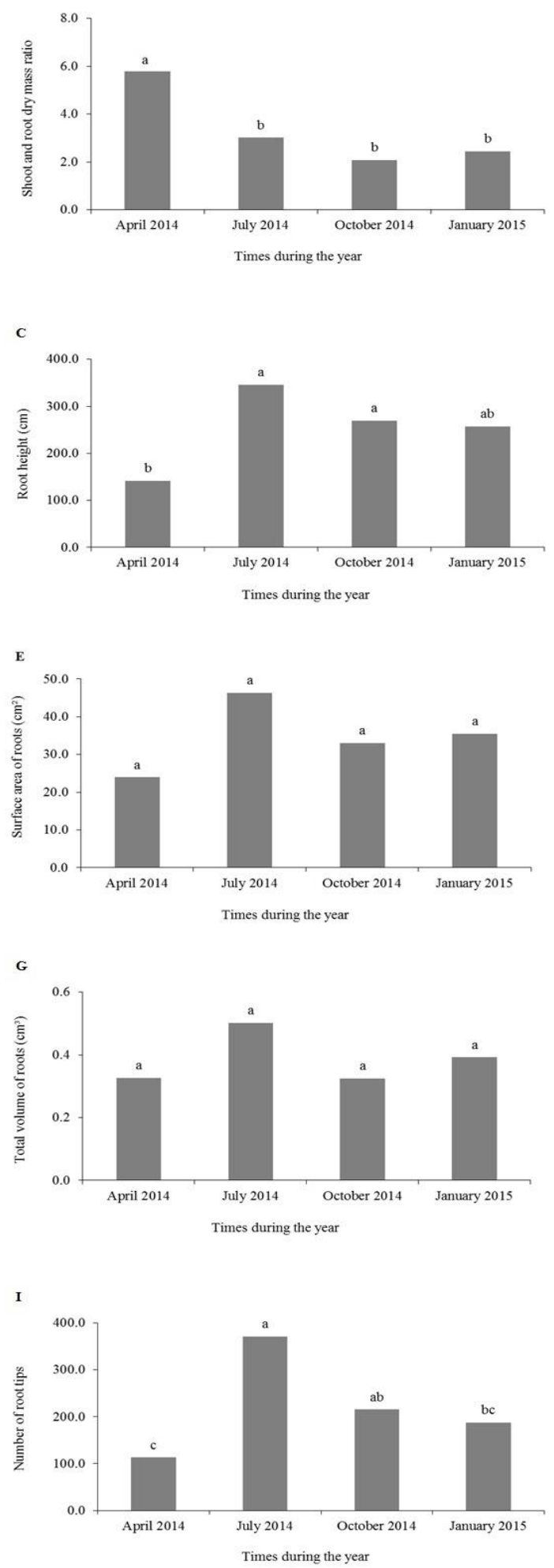

B

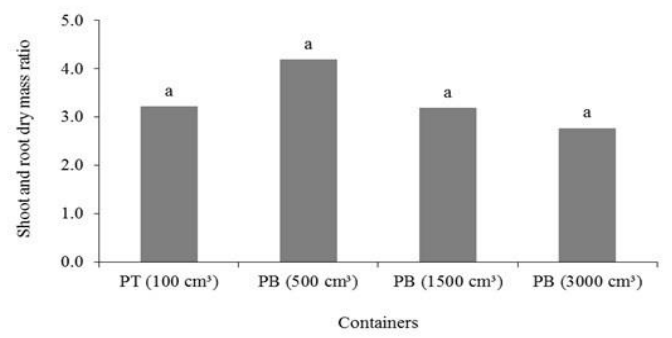

D
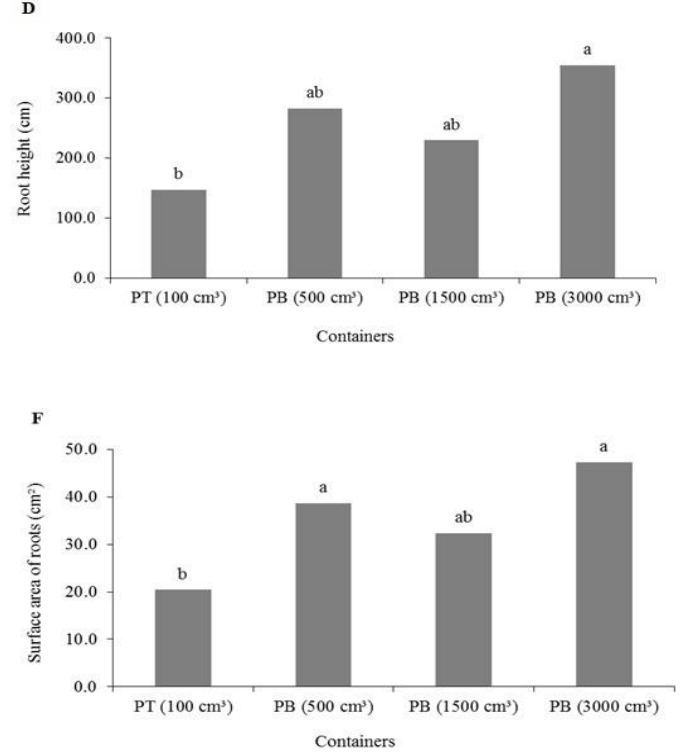

H

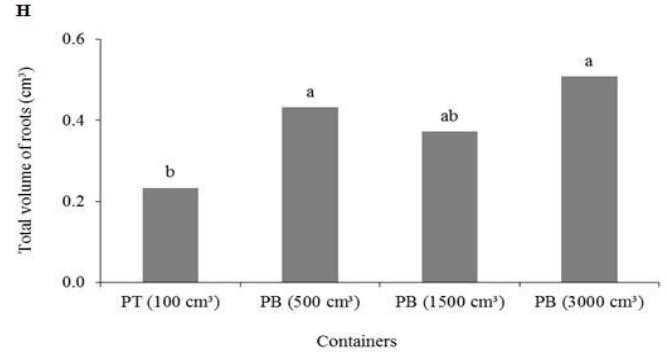

$\mathbf{J}$

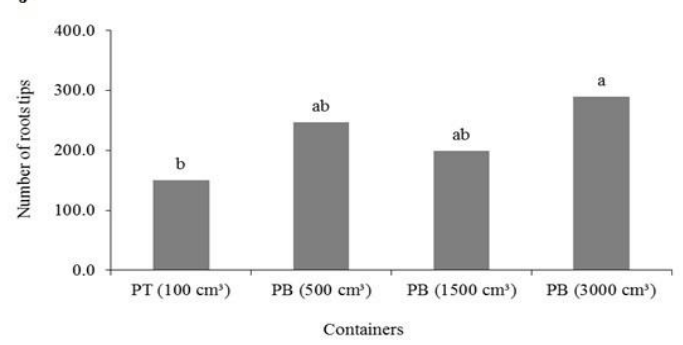


For the surface area and total root volume, there were no significant differences between the season of the year, and the highest means were found in the mini-cuttings collected in July $\left(46.3 \mathrm{~cm}^{2}\right.$ and 0.5 $\mathrm{cm}^{3}$, respectively) (Figures $3 \mathrm{E}$ and $3 \mathrm{G}$ ). However, the total length, number of root tips and Dickson quality index were significantly influenced by the season (Figures 3C, 3I and 4A). For these variables, the highest means were found in the plantlets produced from mini-cuttings collected in July, followed by the months of October and January, while the lowest means were found in April. These results corroborate with those obtained for shoot to root relation and indicate that yerba mate minicuttings can be collected from July to January, resulting in the production of plantlets with high morphophysiological quality. This is because the plantlets produced in July present their growth period between the months of October to January (spring and summer), which present higher average of air temperatures $\left(23.9^{\circ} \mathrm{C}\right)$. There is an increase in the transpiration rate at this time of year, which in turn can lead to the development of roots in deeper and more humid layers of soil as an alternative to avoid water deficit (HSIAO; XU, 2000). Similarly, lower responses were obtained in mini-cuttings collected in April, since their growth occurred during the period from July to October with low temperature average $\left(18.5{ }^{\circ} \mathrm{C}\right)$, when plants experiment vegetative rest.
Container type and substrate volume did not significantly influence the Dickson quality index and relationship between dry mass of the shoots and roots of yerba mate plantlets in all evaluations (Figures 4B and 3B). Similarly, Lisboa et al. (2012) found no significant effect on the relationship between dry mass of the shoot and roots of Calophyllum brasiliense Cambess seedlings cultivated in containers with different volumes (115, 180 and $280 \mathrm{~cm}^{3}$ ), indicating that the containers afforded balanced growth between the shoot and roots. The means obtained for the Dickson's quality index were between 0.07 and 0.10 (Figure 4B). These values are similar to those found in exotic tree species Eucalyptus grandis W. Hill and Pinus elliottii Engelm., ranging from 0.01 to 0.05 and 0.01 to 0.16 , respectively, at 120 days after emergence (BINOTTO, 2007). In the native tree species Schinus terebinthifolius Raddi, the Dickson quality index values were higher, ranging from 0.59 (150 $\mathrm{cm}^{3}$ tube container) to $2.37\left(2250 \mathrm{~cm}^{3}\right.$ plastic bag) (JOSÉ et al., 2005). In general, Dickson quality index values above 0.20 correspond to high quality seedlings (HUNT, 1990), however this parameter may vary depending on the management used in the nursery, the type and proportion of substrate, the volume of the container, the age of the evaluated seedlings and, especially, the species under study (CALDEIRA et al., 2012).

Figure 4. Dickson quality index (DQI) of yerba mate plantlets produced by mini-cutting in four different seasons of the year (A) and cultivated in different containers (B), regardless of the genetic material, at 120 days of cultivation. $\mathrm{PB}=$ polyethylene bags and $\mathrm{PT}=$ polyethylene tube containers. Treatments followed by the same letter do not differ by the Tukey test at $5 \%$ error probability.
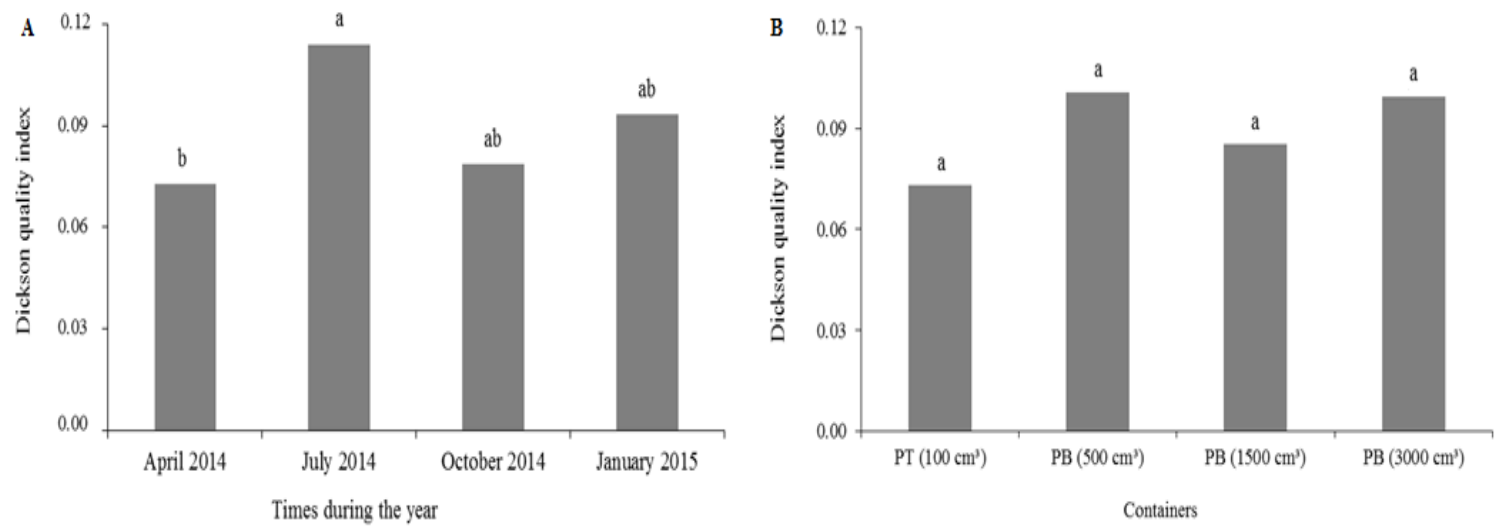
The container type and volume had no significant effect on survival percentage, which presented a mean of $85.1 \%$ at 120 days of cultivation (Figure 5A). Survival percentages between 61.7 and $75.0 \%$ were found at 120 days of cultivation, regardless of the container used $\left(1500,3000\right.$ and $6000 \mathrm{~cm}^{3}$ plastic bags and $50 \mathrm{~cm}^{3}$ tube containers) in the cultivation of seedlings of native species Maytenus ilicifolia Martius ex Reissek (NICOLOSO et al., 2000). The results for survival of seminal seedlings from vegetative propagation show that yerba mate plantlets had good adaptability to the cultivation environment and the management used in the nursery phase. This hypothesis is supported by the fact that vegetative propagation involves a series of steps, such as the transfer of rooting substrate to growth substrate and the change in environment, which are not involved in seedling seminal production and may reduce survival and limit the clonal production of plantlets.

Figure 5. Survival percentage (A), number of leaves (B), shoot height (C), and stem diameter (D) of yerba mate plantlets produced by mini-cutting in different containers, regardless of the genetic material, at 30, 60, 90 and 120 days of cultivation. $\mathrm{PB}=$ polyethylene bags and $\mathrm{PT}=$ polyethylene tube containers. Treatments followed by the same letter do not differ by the Tukey test at $5 \%$ error probability.
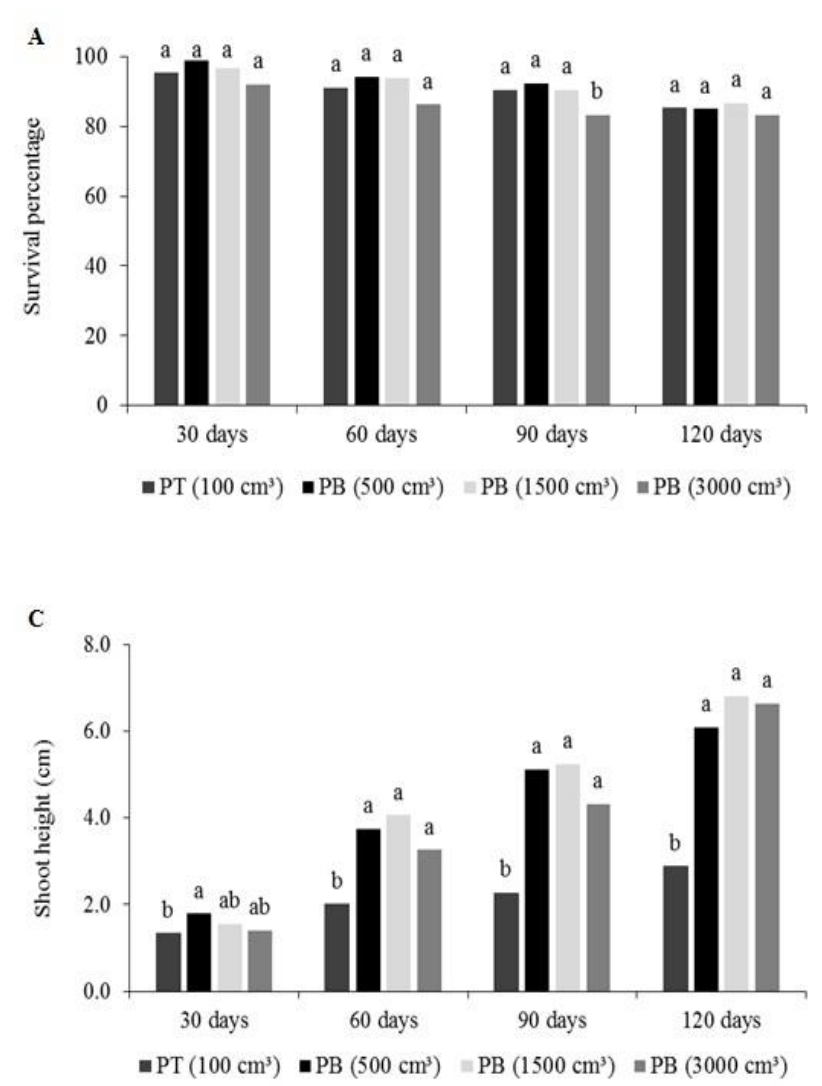

There was also no significant effect of container type and volume on stem diameter, with values ranging from 2.29 to $2.55 \mathrm{~mm}$ (Figure 5D). This variable is the best performance indicator after planting (RITCHIE; LANDIS, 2008), although there
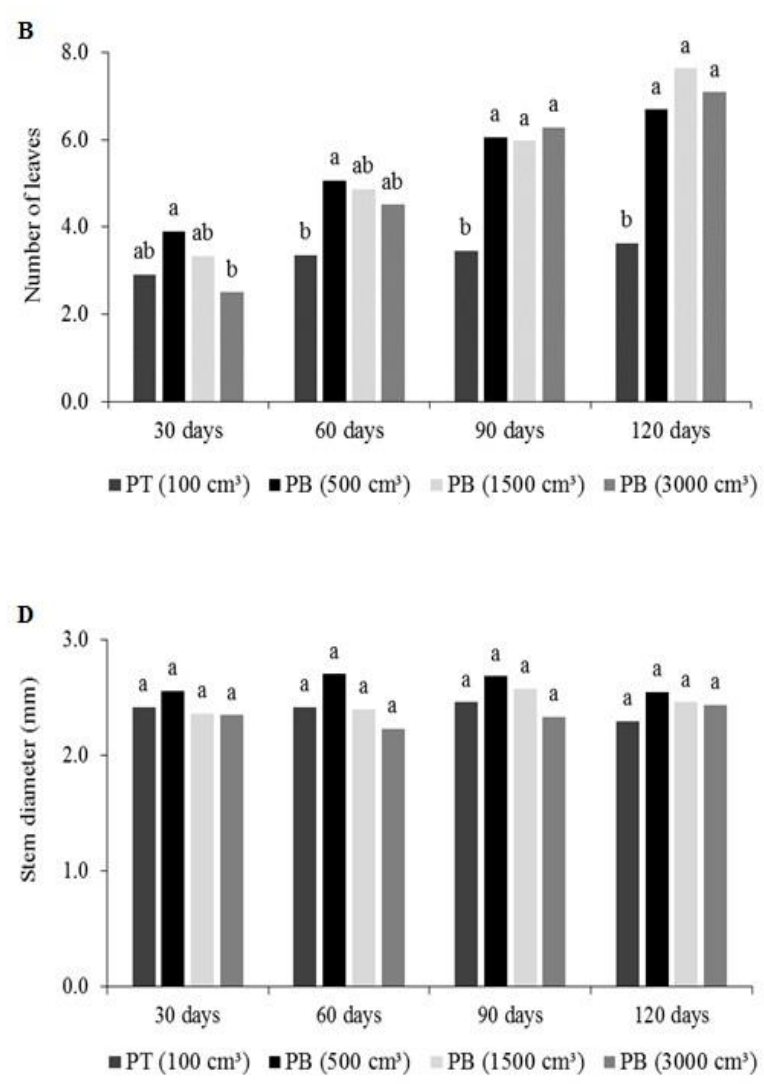

are no standardized reference values, especially for different native tree species. According to Hines and Long (1986), plants with a stem diameter equal to or greater than $2.5 \mathrm{~mm}$ can be discarded. On the other hand, Gonçalves et al. (2000) affirmed that 
seedlings must present stem diameter from 5 to $10 \mathrm{~mm}$ in order to be considered high quality. In this sense, we emphasize the need for studies that evaluate the ideal stem diameter range for each species since according to Landis et al. (2010) this is a variable influenced by genotype, nursery conditions and seedling planting.

The container type and volume had a significant main effect on number of leaves, shoot height and shoot height/stem diameter relation $(\mathrm{P}<0.05)$ in all evaluations. The highest number of leaves and shoot height were observed in plantlets cultivated in polyethylene bags, regardless of the volume (500, 1500 and $3000 \mathrm{~cm}^{3}$ ) when compared to plantlets produced in polyethylene tube containers (Figures 5B and 5C). Similar results were observed in Cedrela fissilis Vell., Anadenanthera macrocarpa Brenan and Bauhinia forficate Link seedlings, where increased container size positively influenced both the number of leaves and shoot height of the seedlings (ANTONIAZZI et al., 2013; ALVES et al., 2012; VIANA et al., 2008). These responses may be associated with the higher volume of substrate contained in the polyethylene bags resulting in greater availability of nutrients for seedling development, where as in the tube containers there amount of nutrients available to the root system is limited, consequently affecting distribution for shoot and plantlet growth (CARVALHO FILHO et al., 2004).

The relation between shoot height and stem diameter of seedlings cultivated in polyethylene bags, regardless of the volume, presented a mean of 2.65 , which is significantly higher than the polyethylene tube containers (1.38) at 120 days of cultivation. This relationship should be less than 10 for the seedlings produced in order to be considered a suitable quality standard (BIRCHLER et al., 1998). Thus, the yerba mate plantlets produced in the four containers studied presented balanced growth between the shoot and stem diameter, which provides greater resistance and better fixation of the plantlets in the soil when planted in the field (ARTUR et al., 2007).
The containers significantly affected the length, surface area, total volume and number of root tips of the yerba mate plantlets. The highest responses were observed in the seedlings produced in 500, 1500 and $3000 \mathrm{~cm}^{3}$ polyethylene bags (Figures 3 and 6A) when compared to the tube containers (Figures 3 and $6 \mathrm{~B})$. This result can be explained by the volume of substrate of the polyethylene bag being, respectively, 5, 15 and 30 times greater than the volume of the rigid polyethylene tube containers, which enabled increased growth, spatial distribution and higher morphological and physiological quality of the roots. Similar results were observed in seedlings of natural hybrids of Eucalyptus grandis W. Hill. and Eucalyptus saligna Sm. produced by mini-cutting in $50 \mathrm{~cm}^{3}$ tube containers, which presented restricted root system growth (FREITAS et al., 2006).

In general, regarding mini-cutting collection periods, high-quality morphophysiological plantlets can be produced by mini-cutting when they are collected between the months of July and January. It is important to note that this study was conducted in a greenhouse, and the differences observed in mini-cutting plantlets collected in April may be minimized under field conditions (ABREU et al., 2015). In relation to the containers, polyethylene bags enabled the production of high quality morphophysiological yerba mate plantlets when compared to plantlets produced in tube containers. It is important to consider that no base and/or cover fertilizations were performed in this study. Thus, it is likely that there were not enough nutrients provided by the lower volume of substrate in the tube, associated to greater leaching losses, to propitiate the growth of the plantlets. Further studies should be carried out to evaluate the performance of yerba mate plantlets under field conditions, as well as to evaluate polyethylene tubes with a higher volume of substrate and the effect of base and cover fertilizations on the morphological and physiological quality of yerba mate plantlets produced by mini-cutting. 
Figure 6. Root system of yerba mate plantlets produced by mini-cutting and cultivated in $1500 \mathrm{~cm}^{3}$ polyethylene bags (A) and $100 \mathrm{~cm}^{3}$ rigid polyethylene tube containers (B), regardless of the genetic material, at 120 days of cultivation. Bar $=1 \mathrm{~cm}$.

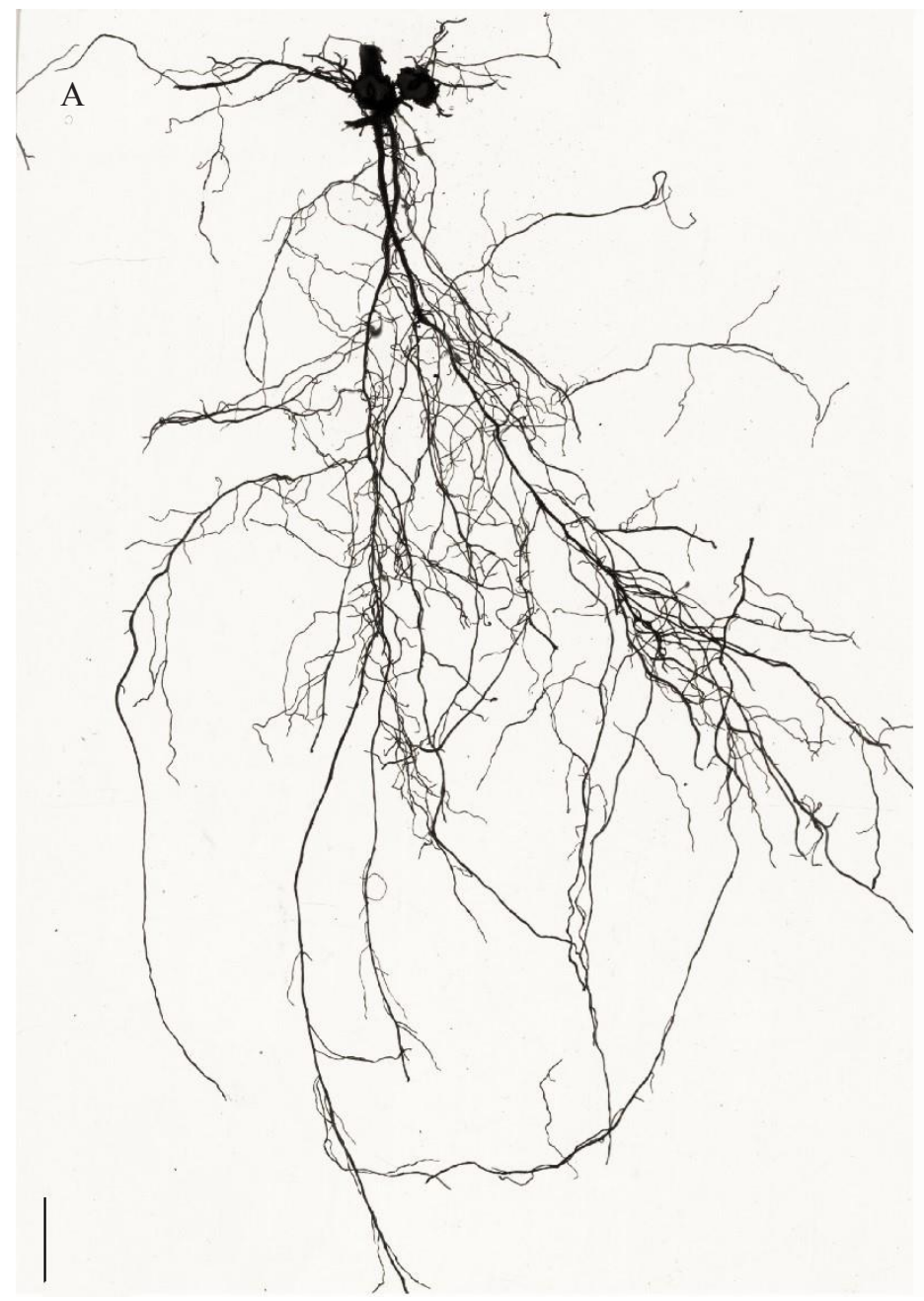

B

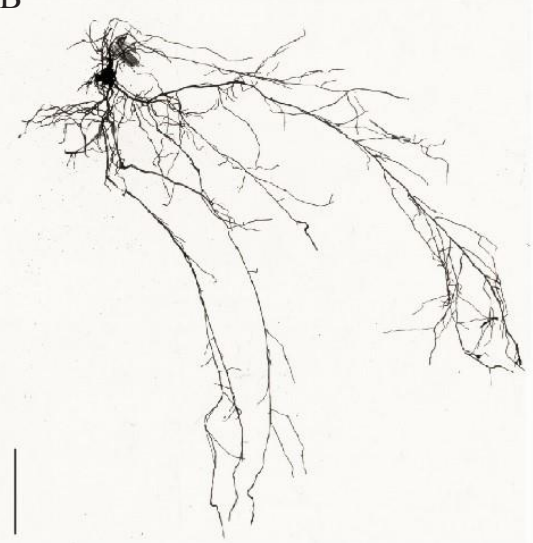

\section{Conclusion}

Yerba mate plantlets with high morphophysiological quality can be produced by mini-cutting collected during the months from July to January and cultivated in polyethylene bags.

\section{Acknowledgements}

The authors are grateful to the Brazilian Council of Technological and Scientific Development (CNPq) for scholarships.

\section{References}

ABREU, A. H. M.; LELES, P. S. S.; MELO, L. A.; FERREIRA, D. H. A. A.; MONTEIRO, F. A. S. Produção de mudas e crescimento inicial em campo de Enterolobium contortisiliquum produzidas em diferentes recipientes. Revista Floresta, Curitiba, v. 45, n. 1, p. 141$150,2015$.

AJALA, M. C.; AQUINO, N. F.; MALAVASI, U. C.; MALAVASI, M. M. Efeito do volume do recipiente na produção de mudas e no crescimento inicial de Jatropha curcas L. no Oeste Paranaense. Semina: Ciências Agrárias, Londrina, v. 33, n. 6, p. 2039-2046, 2012. 
ALFENAS, A. C.; ZAUZA, E. A. V.; MAFIA, R. G.; ASSIS, T. F. Clonagem e doenças do eucalipto. 2. ed. Viçosa, MG: Universidade Federal de Viçosa, 2009. 500 p.

ALMEIDA, L. S.; MAIA, N.; ORTEGA, A. R.; ANGELO, A. C. Crescimento de mudas de Jacaranda puberula Cham. em viveiro submetidas a diferentes níveis de luminosidade. Revista Ciência Florestal, Santa Maria, v.15, n. 3, p. 323-329, 2005.

ALVES, A. S.; OLIVEIRA, L. S. B.; ANDRADE, L. A.; GONÇALVES, G. S.; SILVA, J. M. Produção de mudas de angico em diferentes tamanhos de recipientes e composições de substratos. Revista Verde, Mossoró, v. 7, n. 2, p. 39-44, 2012.

ANTONIAZZI, A.P.; BINOTTO, B.; NEUMANN, G. M.; SAUSEN, T. L.; BUDKE, J. C. Eficiência de recipientes no desenvolvimento de mudas de Cedrela fissilis Vell. (Meliaceae). Revista Brasileira de Biociencias, Porto Alegre, v. 11, n. 3, p. 313-317, 2013.

ARTUR, A. G.; CRUZ, M. C. P.; FERREIRA, M. E.; BARRETTO, V. C. M.; YAGI, R. Esterco bovino e calagem para formação de mudas de guanandi. Revista Pesquisa Agropecuária Brasileira, Brasília, v. 42, n. 6, p .843-850, 2007.

BANDINELLI, M. G.; BISOGNIN, D. A.; GNOCATO, F. S.; MAMBRIN, R. B.; SAUSEN, D.; NICOLOSO, F. T. Concentração dos sais e da sacarose do meio MS na multiplicação in vitro e na aclimatização de batata. Revista Horticultura Brasileira, Brasília, v. 31, n. 2, p. 242-247, 2013.

BARNETT, Y. P. Maturation of tree seeds. In: SYMPOSIUM ON FLOWERING AND SEED DEVELOPMENT IN TREES, 1979, Starkville. Proceedings...Starkville: USDA. Forest Service, 1979, p. 206-217.

BINOTTO, A. F. Relação entre variáveis de crescimento e o indice de qualidade de Dickson em mudas de Eucalyptus grandis W. Hill ex Maid e Pinus elliottii var.Elliottii Engelm. 2007. Dissertação (Mestrado em Engenharia Florestal) - Universidade Federal de Santa Maria, Santa Maria.

BIRCHLER, T.; ROSE, R. W.; ROYO, A.; PARDOS, M. La planta ideal: revisión del concepto, parámetros definitorios e implementaction practica. Investigacion Agraria, Sistemas y Recursos Forestales, Madrid, v. 7, n. 1-2, p. 109-121, 1998.

CALDEIRA, M. V. W.; PERONI, L.; GOMES, D. R.; DELARMELINA, W. M.; TRAZZI, P. A. Diferentes proporções de biossólido na composição de substratos para a produção de mudas de timbó (Ateleia glazioveana Baill). Revista Scientia Forestalis, Piracicaba, v.40, n. 93, p. 15-22, 2012.

CARNEIRO, J. G. A. Produção e controle de qualidade de mudas florestais. Curitiba: UFPR/FUPEF, 1995. 451 p.

CARVALHO, P. E. R. Espécies arbóreas brasileiras. Brasília: Embrapa Informação Tecnológica; Colombo: Embrapa Florestas. 2003. 1039 p.

CARVALHO FILHO, J. L.; ARRIGONI-BLANK, M. F.; BLANK, A. F. Produção de mudas de angelim (Andira fraxinifolia Benth.) em diferentes ambientes, recipientes e substratos. Revista Ciência Agronômica, Fortaleza, v.35, n. 1, p. 61-67, 2004.

DICKSON, A.; LEAF, A. L.; HOSNER, J. F. Quality appraisal of white spruce and white pine seedling stock in nurseries. The Forestry Chronicle, Mattawa, v. 36, n. 1, p. 10-13, 1960.

DOMINGUEZ-LERENA, S.; SIERRA, N. H.; MANZANO, I. C.; BUENO, L. O.; RUBIRA, J. L. P.; MEXAL, J. G. Container characteristics influence Pinus pinea seedling development in the nursery and field. Forest Ecology and Management, Amsterdam, v. 221, n.1-3, p. 63-71, 2006.

DUMROESE, R. K.; LUNA, T.; LANDIS, T. D. Nursery manual for native plants: a guide for tribal nurseries. Washington: U.S. Department of Agriculture, Forest Service, 2009. $302 \mathrm{p}$.

FERRIANI, A. P.; ZUFFELLATO-RIBAS, K. C.; WENDLING, I. Miniestaquia aplicada a espécies florestais. RevistaAgro@mbiente On-line, Boa Vista, v. 4, n. 2, p. 102-109, 2010.

FREITAS, T. A. S.; BARROSO, D. G.; CARNEIRO, J. G. A.; PENCHEL, R. M.; FIGUEIREDO, F. A. M. M. A. Mudas de eucalipto produzidas a partir de miniestacas em diferentes recipientes e substratos. Revista Árvore, Viçosa, MG, v. 30, n. 4, p. 519-528, 2006.

GASPARIN, E.; AVILA, A. L.; ARAUJO, M. M.; CARGNELUTTI FILHO, A.; DORNELES, D. U.; FOLTZ, D. R. B. Influência do substrato e do volume de recipiente na qualidade das mudas de Cabralea canjerana (Vell.) Mart. em viveiro e no campo. Revista Ciência Florestal, Santa Maria, v. 24, n. 3, p. 553-563, 2014.

GNOATTO, S. C. B.; BASSANI, V. L.; COELHO, G. C.; SCHENKEL, E. P. Influência do método de extração nos teores de metilxantinas em erva-mate (Ilex paraguariensis A. St.-Hil., aquifoliaceae). Química Nova, São Paulo, v.3 0, n. 2, p. 304-307, 2007. 
GONÇALVES, J. L. M.; SANTARELLI, E. G.; MORAES NETO, S. P.; MANARA, M. P. Produção de mudas de espécies nativas: substrato, nutrição, sombreamento e fertilização. In: GONÇALVES, J. L. M.; BENEDETTI, V. (Ed.). Nutrição e fertilização florestal. Cidade: Editora, 2000. p. 309-350.

GOMES, J. M.; COUTO, L.; BORGES, R. C. G.; FREITAS, S. C.Influência do tamanho da embalagem plástica na produção de mudas de ipê (Tabebuia serratifolia), de copaíba (Copaifera langsdorffii) e de angico-vermelho (Piptadenia peregrina). Revista Árvore, Viçosa, MG, v. 14, n. 1, p. 26-34, 1990.

HAMMAN, R. A.; WALSH, T. M.; STUSHNOFF, C. Seasonal carbohydrate changes and cold hardiness of chardonnay and riesling grapevines.American Journal of Enology and Viticulture, Prosser, v. 47, n. 1, p.31-36, 1996.

HARTMANN, H. T.; DALE, E. K. Propagación de plantas. México city: Continental, 1975. $662 \mathrm{p}$.

HINES, F. D.; LONG, A. J. First- and second-year survival of containerized Engelmann spruce in relation toinitial seedling size. Canadian Journal of Forest Research, Ottawa, v. 16, n. 3, p. 668-670, 1986.

HSIAO, T. C.; XU, L. K. Sensitivity of growth of roots versus leaves to water stress: biophysical analysis and relation to water transport. Journal of Experimental Botany, Colchester, v. 51, n. 350, p. 1595-1616, 2000.

HUNT, G. A. Effect of styroblock design and cooper treatment on morphology of conifer seedlings. In: TARGET SEEDLING SYMPOSIUM, MEETING OF THE WESTERN FOREST NURSERY ASSOCIATIONS, GENERAL TECHNICAL REPORT RM-200, 1990, Roseburg. Proceedings... Fort Collins: United States Department of Agriculture, Forest Service, 1990. p. 218-222.

INSTITUTO BRASILEIRO DE GEOGRAFIA E ESTATÍSTICA - IBGE. Biblioteca.Produção da extração vegetal e da silvicultura. Cidade: Editora, 2012. Disponível em: <http://servicodados.ibge.gov.br/ Download/Download.ashx?http=1\&u=biblioteca.ibge. gov.br/visualizacao/periodicos/74/pevs_2012_v27.pdf . Acesso em: 25 jul. 2016.

JOSÉ, A. C.; DAVIDE, A. C.; OLIVEIRA, S. L. Produção de mudas de aroeira (Schinus terebinthifolius Raddi) para recuperação de áreas degradadas pela mineração de bauxita. Revista Cerne, Lavras, v. 11, n. 2, p. 187-196, 2005.
KOSTOPOULOU, P.; RADOGLU, K.; PAPANASTASI, O. D. Effect of mini-plug container depth on root and shoot growth of four forest tree species during early developmental stages. Turkish Journal of Agriculture and Forestry, Erzurum, v. 35, n. 1, p. 379-390, 2011.

LANDIS, T. D.; DUMROESE, R. K.; HAASE, D. L. The container tree nursery manual: seedling processing, storage, and out planting. Washington: Department of Agriculture Forest Service, 2010. v. 7, 194 p.

LEAL, C. C. P.; TORRES, S. B.; FREITAS, R. M. O.; NOGUEIRA, N. W.; FARIAS, R. M. Light intensity and type of container on producing Cassia grandis $\mathrm{L}$. F. seedlings. Revista Brasileira de Engenharia Agrícola e Ambiental, Campina Grande, v. 19, n. 10, p. 939-945, 2015.

LIMA, R. L. S.; SEVERINO, L. S.; SILVA, M. I. L.; VALE, L. S.; BELTRÃO, N. E. M. Volume de recipientes e composição de substratos para produção de mudas de mamoneira. Revista Ciência e Agrotecnologia, Lavras, v. 30, n. 3, p. 480-486, 2006.

LISBOA, A. C.; SANTOS, P. S. dos; OLIVEIRA NETO, S. N. de; CASTRO, D. N. de; ABREU, A. H. M. Efeito do volume de tubetes na produção de mudas de Calophyllum brasiliense e Toona ciliata. Revista Árvore, Viçosa, MG, v. 36, n. 4, p. 603-609, 2012.

LUZ, J. M. Q.; SILVA, S. M.; HABBER, L. L.; MARQUEZ, M. O. M. Produção de óleo essencial de Melissa officinalis L. em diferentes épocas, sistemas de cultivos e adubações. Revista Brasileira de Plantas Medicinais, Botucatu, v. 16, n. 3, p. 552-560, 2014.

NICOLOSO, F. T.; FORTUNATO, R. P.; ZANCHETTI, F.; CASSO, L. F.; EISINGER, S. M. Recipientes e substratos na produção de mudas de Maytenus ilicifolia e Apuleia leiocarpa. Revista Ciência Rural, Santa Maria, v. 30, n. 6, p. 987-992, 2000.

QUEIROZ, J. A.; MELÉM JÚNIOR, N. J. Efeito do tamanho do recipiente sobre o desenvolvimento de mudas de açaí (Euterpe oleracea Mart.). Revista Brasileira de Fruticultura, Jaboticabal, v. 21, n. 1, p. 460-462, 2001.

RITCHIE, G. A.; LANDIS, T. D. The container tree nursery manual. USDA, 2008, v. 7, 200 p. (Agricultural Handbook 674). Available at: <http://www.rngr.net/ Publications/ctnm/volume7>. Accesse dat: 11 abr. 2017.

SANTOS, C. B.; LONGUI, S. J.; HOPPE, J. M.; MOSCOVICH, F. A. Efeito do volume de tubetes e tipos de substratos na qualidade de mudas de Cryptomeria japonica (L. f.) D. Don. Revista Ciência Florestal, Santa Maria, v. 10, n. 2, p. 1-15, 2000. 
SOUZA, C. C.; XAVIER, A.; LEITE, F. P.; SANTANA, R. C.; LEITE, H. G. Padrões de miniestacas e sazonalidade na produção de mudas clonais de Eucalyptus grandis Hill X E. urophylla S. T. Black. Revista Árvore, Viçosa, MG, v. 37, n. 1, p. 67-77, 2013.

STENZEL, N. M. C.; NEVES, C. S. V. J.; MARUR, C. J.; GOME, J. C. Crescimento vegetativo de plantas cítricas no norte e noroeste do Paraná. Revista Brasileira de Fruticultura, Jaboticabal, v. 27, n. 3, p. 412-417, 2005.

VIANA, J. S.; GONÇALVEZ, E. P.; ANDRADE, L. A.; OLIVEIRA, L. S. B.; SILVA, E. O. Crescimento de mudas de Bauhinia forficata Link. em diferentes tamanhos de recipientes. Revista Floresta, Curitiba, v. 38, n. 4, p. 663-671, 2008.
WAKELEY, P. C. Planting the sauthern pines. Waschington: V. S. Dep. Agr., 1954. 233 p.

WENDLING, I.; DUTRA, L. F.; GROSSI, F. Produção e sobrevivência de miniestacas e minicepas de ervamate cultivadas em sistema semi-hidropônico. Pesquisa Agropecuária Brasileira, Brasília, v. 42, n. 2, p. 289-292, 2007.

XAVIER, A.; COMÉRIO, J. Microestaquia: uma maximização da micropropagação de Eucalyptus. Revista Árvore, Viçosa, MG, v. 20, n. 1, p. 9-16, 1996. 